\title{
Mature cystic teratoma presenting as suprarenal mass
}

\author{
Ravi Banthia (1), ${ }^{1}$ Priyank Yadav, ${ }^{1}$ Anju Bharti, ${ }^{2}$ Hira Lal ${ }^{3}$
}

${ }^{1}$ Urology and Renal Transplant, Sanjay Gandhi Postgraduate Institute of Medical Sciences, Lucknow, Uttar Pradesh, India ${ }^{2}$ Pathology, Institute of Medical Sciences, Banaras Hindu University, Varanasi, Uttar Pradesh, India

${ }^{3}$ Radiodiagnosis, Sanjay Gandhi Post Graduate Institute of Medical Sciences, Lucknow, Uttar Pradesh, India

\section{Correspondence to Dr Hira Lal; hiralal2007@yahoo.co.in}

Accepted 9 July 2020

Check for updates

(c) BMJ Publishing Group Limited 2020. No commercial re-use. See rights and permissions. Published by BMJ.

To cite: Banthia R, Yadav $P$, Bharti $A$, et al. BMJ Case Rep 2020;13:e237734. doi:10.1136/bcr-2020237734

\section{DESCRIPTION}

A 4-year-old girl was noticed to have abdominal distension by her parents. On evaluation with ultrasound, there was a heterogeneous solid cystic lesion with a predominantly cystic component seen in the left suprarenal region. Contrast enhanced CT (CECT) of the abdomen revealed a large $11 \times 11.5 \times 13 \mathrm{~cm}$ multiloculated, hypodense cystic lesion with fat attenuation and long bone within the cystic cavity in the left suprarenal region causing compression and displacement of the left kidney (figure 1). Features were suggestive of teratoma. The endocrine workup for adrenal tumour was normal. Tumour markers which included Alpha Fetoprotein (AFP), Human Chorionic Gonadotropin (HCG) and Lactate Dehydrogenase (LDH) were within normal limits.

The child underwent explorative laparotomy and intraoperatively a large mass was seen replacing and pressing on the left kidney. Dense adhesions were present between tumour and gut loops, spleen and lateral wall. The tumour was also adherent to the aorta and inferior vena cava, but there was no invasion of these structures or any major blood vessel. Mass was well encapsulated and no infiltration of normal renal parenchyma was seen. Complete excision of left suprarenal mass was done. Left adrenal and bilateral ovaries were normal.

Histopathological examination showed cheesy whitish pultaceous material along with hair, bone and cartilage suggesting structures derived from the different embryonic germ layers. The cyst walls were lined by stratified squamous epithelium. No immature elements were seen, findings were suggestive of mature cystic teratoma (figure 2). No adrenal tissue or malignant component was seen. After surgery, the child had an uneventful recovery and at 12 months of follow-up, there is no abdominal distension on clinical examination and no recurrent lesion on ultrasonography. Follow-up AFP, HCG and LDH are also normal.

Teratomas are among the most common congenital tumour comprising of tissues arising from pluripotent embryonic cells. ${ }^{1}$ They are frequently seen in gonads. The most common site of extragonadal germ cell tumour is the sacrococcygeal region, mediastinum, head and neck, and retroperitoneum. ${ }^{2}$ A retroperitoneal teratoma constitutes $1 \%-11 \%$ of primary retroperitoneal neoplasm in children and $3 \%-4 \%$ of all germ cell tumours. ${ }^{34}$ The majority of these tumours are found in the pararenal area and are more common on the left side as in index case. There is bimodal presentation, with peak in first 6 months of life and early adulthood. They usually

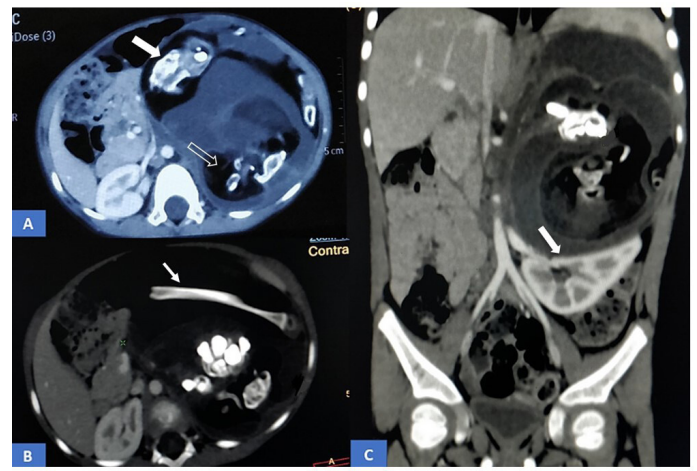

Figure 1 (A, B) Contrast enhanced CT (CECT) abdomen in axial plane showing well-defined lesion on left suprarenal location with intralesional fatty attenuation (hollow arrow) with bony elements (solid arrow) and long bone (line arrow). (C) CECT abdomen in coronal plane shows displacement of left kidney with extrinsic effect on upper pole calyx (solid arrow).

present as progressive abdominal distension and palpable abdominal lump. ${ }^{5}$

Ultrasound of the abdomen is the first imaging modality used, CECT abdomen is the imaging modality of choice and is helpful in showing the extent of disease in retroperitoneum, and involvement of blood vessels. ${ }^{6}$ Although benign, teratomas can encase major blood vessels. The serum alphafetoprotein and HCG levels are good indicators

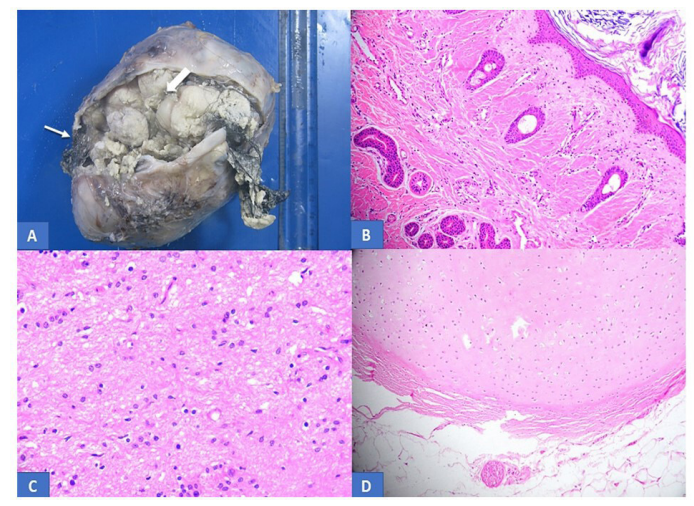

Figure 2 (A) Cut surface of resected globular soft cystic mass, showing cheesy whitish pultaceous material along with hair (line arrow), bone and cartilage (solid arrow). (B) Histopathological examination (H\&E stain) shows Cyst walls were lined by stratified squamous epithelium and shows keratin flakes, skin appendageal structures representing ectodermal components. (C) Histopathology showing glial tissue. (D) Histopathology picture showing mature cartilage with adipose tissue and nerve bundles. 
for diagnosis and elevation of either marker may indicate the presence of malignant germ cell elements. ${ }^{7}$ However, the final diagnosis is made on pathological examination of resected specimen. Complete resection is the treatment of choice, which is recommended in all cases. ${ }^{8}$ Malignancy is uncommon in mature cystic teratoma and the prognosis is favourable with an $80 \%-100 \%$ survival reported after complete surgical excision of the tumour. ${ }^{9}$

\section{Patient's perspective}

Patient's father: I was told by my doctor that my daughter has a mass in her abdomen, which may or may not be malignant but will require removal by surgery. The surgery went on well. I was happy to know that the tissue report did not show any cancer. Presently, my daughter is doing well and I am very happy that her case was managed very well by the team. I am on regular follow-up as advised by my doctors.

\section{Learning points}

- Retroperitoneal mature cystic teratoma usually presents within 6 months of age or in adulthood but may present in young children.

- It generally presents with abdominal distension and early diagnosis can be made by ultrasound and CT scan.

- The diagnosis is confirmed by histopathological examination of resected specimen.

Twitter Ravi Banthia @ecstaticscalpel
Contributors This report was supervised by HL. Data were compiled and case report was written by RB. Manuscript review was done by PY. Histopathological diagnosis and explanation was given by $A B$.

Funding The authors have not declared a specific grant for this research from any funding agency in the public, commercial or not-for-profit sectors.

Competing interests None declared.

Patient consent for publication Parental/guardian consent obtained.

Provenance and peer review Not commissioned; externally peer reviewed.

\section{ORCID iD}

Ravi Banthia http://orcid.org/0000-0001-8723-9732

\section{REFERENCES}

1 Heerema-McKenney A, Harrison MR, Bratton B, et al. Congenital teratoma: a clinicopathologic study of 22 fetal and neonatal tumors. Am J Surg Pathol 2005:29:29-38.

2 Woodward PJ, Sohaey R, Kennedy A, et al. From the Archives of the AFIP: a comprehensive review of fetal tumors with pathologic correlation. Radiographics 2005:25:215-42.

3 Marina NM, Cushing B, Giller R, et al. Complete surgical excision is effective treatment for children with immature teratomas with or without malignant elements: a pediatric oncology Group/Children's cancer group intergroup study. J Clin Oncol 1999:17:2137-43

4 Grosfeld JL, Billmire DF. Teratomas in infancy and childhood. Curr Prob/ Cancer 1985:9:1-53.

5 Patil PS, Kothari P, Gupta A, et al. Retroperitoneal mature cystic teratoma in a neonate: a case report. J Neonatal Surg 2016:5:15.

6 Peyvandi H, Arsan F, Alipour-Faz A, et al. Primary retroperitoneal mature cystic teratoma in an adult: a case report. Int J Surg Case Rep 2016;28:285-8.

7 Talerman A, Haije WG, Baggerman L. Serum alphafetoprotein (AFP) in diagnosis and management of endodermal sinus (yolk sac) tumor and mixed germ cell tumor of the ovary. Cancer 1978:41:272-8.

8 Paradies G, Zullino F, Orofino A, et al. Rare extragonadal teratomas in children: complete tumor excision as a reliable and essential procedure for significant survival. clinical experience and review of the literature. Ann Ital Chir 2014;85:56-68.

9 Huddart SN, Mann JR, Robinson K, et al. Sacrococcygeal teratomas: the UK children's cancer Study Group's experience. I. neonatal. Pediatr Surg Int 2003;19:47-51.

Copyright 2020 BMJ Publishing Group. All rights reserved. For permission to reuse any of this content visit

https://www.bmj.com/company/products-services/rights-and-licensing/permissions/

BMJ Case Report Fellows may re-use this article for personal use and teaching without any further permission.

Become a Fellow of BMJ Case Reports today and you can:

- Submit as many cases as you like

- Enjoy fast sympathetic peer review and rapid publication of accepted articles

- Access all the published articles

- Re-use any of the published material for personal use and teaching without further permission

Customer Service

If you have any further queries about your subscription, please contact our customer services team on +44 (0) 2071111105 or via email at support@bmj.com.

Visit casereports.bmj.com for more articles like this and to become a Fellow 